\title{
The effects of the globalization on the German economy
}

\author{
Assist. D-r Tsvetomir Tsvetkov, Chief Assist. D-r Lyubov Ivanova, \\ South West University Neophit Rilski, Blagoevgrad, Bulgaria \\ Department of Economics
}

\begin{abstract}
This article examines the effects of the globalization on Germany's economic growth. The various aspects of the globalization and their impact on German economic development are explored. It is concluded that aggregate globalization and its economic aspect do not have a positive effect on Germany's economic development. On the other hand, the influence of the political and the social globalization, has a positive effect on the economic development of the German economy. Therefore, there is a controversy about the impact of various forms of globalization on Germany's economic growth. This contradiction shows a process of restructuring, but not of stopping the integration of the German economy into the development of the global economic trends.
\end{abstract}

Key words: globalization, economic growth

\section{Introduction}

Germany is the engine of the globalization in Europe and the European Union (EU). It is actively involved in the global economic process of convergence between the European Economic Area and the US Economic Area on one hand, and the European Economic Area and the Chinese economy on the other. Germany, apart from participating in the world global process. Germany, in addition to participating in the global global process, is also involved in the convergence of the economies of EU and European countries, building interconnections between developed, developing countries and LDCs /Low developed countries/. Thus, participating in regional and global cohesion, the German economy is characterized as a developed open economy which, in addition to its positive global effects, is also subject to negative global economic shocks. That is why it is of particular importance to study the impact of the globalization on Germany's economic growth.

This article examines the impact of the globalization on Germany. The main focus of the study is the impact of the aggregate, economic, political and social globalization on the dynamics of the gross domestic product (GDP) in Germany. The purpose of the study is to measure the extent and the direction of the impact of the aggregate, economic, political and social globalization on the dynamics of German economic growth. The objective of the purpose can be achieved by applying the generalized method of moments (GMM), which is a reliable measure of economic structural shocks and interactions that lead to a macroeconomic impact on the development of the economic system. The impact of the globalization and its aspects on economic growth has been examined through theoretical, descriptive and econometric analysis. 


\section{Literature review}

The impact of the globalization on the economy of Germany is examined by Daniel S. Hamilton and Joseph P. Quinlan'. According to them, ,Germany remains one of the largest and most competitive economies in the World thanks in part to globalization" Analyzing the effects of globalization on Germany's economy, the authors conclude that its effects lead to greater economic growth and employment. Hamilton and Quinlan point out that the globalization also poses some challenges to the German economy, such as the dependence on exports and immigrants who do not have the highly skilled jobs required for economic development. Therefore, while the creation of new jobs is increasing in the German economy, unemployment is also increasing, which is a consequence of the low qualifications of immigrant workers. The attachment and convergence of the German economy with the European and Asian economies, as well as with the American economy, more easily subject the German economic system to negative external economic shocks. Axel Dreher ${ }^{3}$ examines the impact of globalization on 123 countries. These 123 countries also consider the impact of the economic, political and social aspects of globalization on Germany. Dreher also calculates a global assessment of the impact of globalization on the economies of these 123 countries, and in particular on the German economy. The results obtained by the aforementioned author boil down to the deepening of the globalization of the German economy, with the global globalization index reaching $3.74^{4}$ percent in 1990 and 5.28 percent in $\mathbf{2 0 0 0}^{5}$. The received results clearly indicate the deepening globalization process in which Germany participates, with political integration most strongly followed by economic integration and social integration. The overall impact of globalization on the economic growth of the 123 countries is positive, according to Dreher. Therefore, the globalization has a positive impact on the German economy. According to Polasek and Sellner, ${ }^{\mathbf{6}}$ the globalization affects the economic development of the countries to varying degrees. They point out that the globalization has greater effects on the less developed regions than in the highly developed regions. Parisa Samimi и Hashem Salarzadeh Jenatabadi ${ }^{7}$ conclude that

\footnotetext{
${ }^{1}$ Hamilton S. D., Quinlan P. J. (2008): „Germany and Globalization“, Washington, DC: Center for Transatlantic Relations. https://www.files.ethz.ch/isn/96218/2008_GermanyandGlobalization_EN.pdf

2 Hamilton S. D., Quinlan P. J. (2008): „Germany and Globalization“, Washington, DC: Center for Transatlantic Relations, p. 3. https://www.files.ethz.ch/isn/96218/2008_GermanyandGlobalization_EN.pdf 3 Dreher, A., (2005): „Does Globalization Affect Growth? Evidence from a new Index of Globalization“, Research Paper Series, TWI and University of Konstanz, pp. 2-19 .

https://pdfs.semanticscholar.org/a5ce/cb531920ca4afffa4faaf94b0098e4989795.pdf

4 Dreher, A., (2005): „Does Globalization Affect Growth? Evidence from a new Index of Globalization“, Research Paper Series, TWI and University of Konstanz, p. 20

https://pdfs.semanticscholar.org/a5ce/cb531920ca4afffa4faaf94b0098e4989795.pdf

5 Dreher, A., (2005): „Does Globalization Affect Growth? Evidence from a new Index of Globalization“, Research Paper Series, TWI and University of Konstanz, p. 20 https://pdfs.semanticscholar.org/a5ce/cb531920ca4afffa4faaf94b0098e4989795.pdf 6 Polasek , W., Sellner , R., (2011): Does Globalization Affect Regional Growth? Evidence for NUTS-2 Regions in EU-27, Institute for Advanced Studies, Economics Series 266, Vienna. https://www.ihs.ac.at/publications/eco/es-266.pdf

7 Samimi, P., Jenatabadi, S. H., (2014): Globalization and Economic Growth: Empirical Evidence on the Role of Complementarities, PLOS ONE. https://www.ncbi.nlm.nih.gov/pmc/articles/PMC3982958/ https://journals.plos.org/plosone/article?id=10.1371/journal.pone.0087824
} 
the effect of the globalization on the economic growth depends on the level of education of workers, the degree of development of the financial system and the level of income of the population. According to the authors, the higher the incomes, the stronger the positive effect of the economic globalization on the economic growth. According to Joseph Eugene $\mathbf{S t i g l i t z}^{8}$, the globalization is a process that can produce positive impulses or negative shocks to the economic development. What will be the outcome of the globalization process depends on its management. Carles Xavier Simo Noguera, Asunción Soro Bonmatí и Teresa Castro-Martin' study the effects of the globalization on the age-related human development. They conclude that the deregulation and the liberalization, which are characteristics of the globalization, lead to greater insecurity in finding a job. The labor market insecurity, on the other hand, makes it more difficult to start families. Joaquin Vial ${ }^{\mathbf{1 0}}$ examines the impact of the globalization on Chile's macroeconomic variables and concludes that the competition in the internal market is intensifying, the access to capitals becomes easier and cheaper, the exports and the imports are stepped up, and the trade barriers are removed. According to him, the globalization contributes to the development of the production capacity through foreign direct investment. Victor. E. Tokman, ${ }^{11}$ examining the effects of the globalization on the Chilean economy, concludes that the globalization is contributing to GDP growth, the poverty reduction, the infrastructure improvement. The foreign direct investment is increasing, through which innovations are transmitted to the Chilean economy. He points out that the globalization, in addition to its positive effects, also leads to negative shocks to the economy. Such negative shocks endure the agriculture and the commercial and the industrial sector, which are made up of local economic agents because they are subject to great external competition. Also, Tokman points out, that the openness of the economy and its convergence with other economies allows for easier transposition of financial and economic crises and, consequently, the transfer of external unemployment to the internal market.

The theoretical review done so far and the interpretation of the theory that embraces the impact of the globalization on the economic development, leads to the following perspective. First, the globalization has a predominantly positive impact on the economic development of the countries that are sufficiently globally integrated. Second, the globalization poses challenges to the integrating economies that, depending on their decision and governance, can be either positive or negative shocks to the economies of the countries participating in the globalization. The conclusions drawn fully correspond to the effects of the globalization on the German economy.

\footnotetext{
${ }^{8}$ Stiglitz, E. J., (2002): „Globalization and Its Discontents“, W. W. Norton \& Company, New York and London, United States of America, First Edition, pp. ix-xi.

${ }^{9}$ Noguera, S.X., Castro - Martin T., Bonmatí S.A., (2005): The Spanish case: The effects of the globalization process on the transition to Adulthood, In book: Globalization, uncertainty and youth in society, Chapter: 15, Publisher: Routledge. Taylor \& Francis Group, pp. 373-381

https://www.researchgate.net/publication/257613737_The_Spanish_case_The_effects_of_the_globali zation_process_on_the_transition_to_adulthood

${ }_{10} \mathrm{Vial}$, A., (2018): Globalisation and the Chilean economy, a chapter in Globalisation and deglobalisation from Bank for International Settlements, vol. 100, pp. 83-100 https://www.bis.org/publ/bppdf/bispap100.pdf

${ }^{11}$ Tokman, E., V., (2010), Globalization in Chile: A Positive Sum of Winners and Losers, International Centre for Trade and Sustainable Development (ICTSD), Geneva, Switzerland, 2010, pp. 33-35. https://www.ictsd.org/sites/default/files/research/2010/12/globalization-in-chile.pdf
} 


\section{Limitations of the study}

The study analyzes the impact of the globalization on Germany's economy. The impact of the globalization in its three aspects, namely economic, political and social, is examined. The study period is from 2000 to 2016. The Eurostat database and the 2018 Globalization Report and Kof.ethz.ch were used (https://kof.ethz.ch/en/forecasts-andindicators/indicators/kof-globalisationindex.html). Променливите, които се разглеждат в настоящето изследване са :

GDP - Gross Domestic Product Current prices, euro per capita

KOF - Index of common globalization

KOFeconomy - Index of economic globalization

KOFSocial - Index of social globalization

KOFPolitics - Index of political globalization

The software product used to conduct the survey is Eviews 10.

\section{Research methodology}

The methodology used is the Dickey-Fuller stationarity test (ADF) and the generalized method of moments (GMM). The process is stationary when it has the following characteristics $^{\mathbf{1 2}}$ :

$$
\begin{aligned}
& \mathrm{E} \mathrm{yt})=\mu \\
& \mathrm{E}(\mathrm{yt}-\mu)(\mathrm{yt}-\mu)=\sigma 2<\infty \\
& \mathrm{E}(\mathrm{yt} 1-\mu)(\mathrm{yt} 2-\mu)=\gamma \mathrm{t} 2-\mathrm{t} 1 \quad \forall \mathrm{t} 1, \mathrm{t} 2
\end{aligned}
$$

A non-stationary process is when:

$$
\mathrm{E}(\mathrm{yt}-\mathrm{E}(\mathrm{yt}))(\mathrm{yt}-\mathrm{s}-\mathrm{E}(\mathrm{yt}-\mathrm{s}))=\gamma \mathrm{s}, \mathrm{s}=0,1,2, \ldots{ }^{13}
$$

Equation (4) shows that the random deviations are not independent in the individual observations.

The Dickey-Fuller (ADF) test can be mathematically described as follows: (5)

$$
\Delta_{t}^{n}=a_{t-1}^{n}+x_{t}^{i}+B_{t}
$$

Where:

$\mathrm{X}_{\mathrm{t}}$ '- exogenous regressors are selected

$\mathrm{p}$ and $\delta$ - are evaluation parameters

$\mathrm{e}_{\mathrm{t}}-$ white noise

$\mathrm{a}=\mathrm{p}-1$

For $\mathrm{H} 0$ : $\mathrm{a}=0$, there is a single root. And for $\mathrm{H} 1$ : $\mathrm{a}<0$ the process is stationary.

\footnotetext{
${ }^{12}$ Brooks, C., (2008): Introductory Econometrics for Finance, second edition, The ICMA Centre, University of Reading, p. 208.

http://www.afriheritage.org/TTT/3\%20Brooks_Introductory\%20Econometrics\%20for\%20Finance\%20(2 nd\%20edition).pdf

${ }^{13}$ Brooks, C.,(2008): Introductory Econometrics for Finance second edition, The ICMA Centre, University of Reading, p. 208.

http://www.afriheritage.org/TTT/3\%20Brooks_Introductory\%20Econometrics\%20for\%20Finance\%20(2 nd\%20edition).pdf
} 
Generalized method of moments (GMM) is a reliable estimator as it does not require information on the exact distribution of disturbances. The summarized method of moments is mathematically expressed by the following function:

$$
\mathrm{E}=(\mathrm{m}(\mathrm{YT}, \beta))=0
$$

The function shows the basic assumption in GMM, which is that $\mathrm{L} \geq \mathrm{K}$, where $\mathrm{L}$ are momentary conditions and $\mathrm{K}$ are measurable parameters. Therefore, GMM associates parameters with moments, extracting information from parameter values that are marked with $\beta$, thus overcoming heteroskedicity, autocorrelations, uncertainty, and non-stationarity. When applying GMM, it is important which method for determining the weight of the matrix will be applied. This study applies the 'HAC-Newey-West' matrix approach.

\section{Dyscriptive analyses}

Germany is one of the main drivers of the globalization, both regionally and globally. It underpins the development of the European Union, as well as being a leading political and economic force in the euro area. Continuing the same perspective on reflections, the question arises: "In which aspect of the globalization does Germany have the greatest involvement in the global convergence process?"

Degree of globalization in Germany

Figure 1

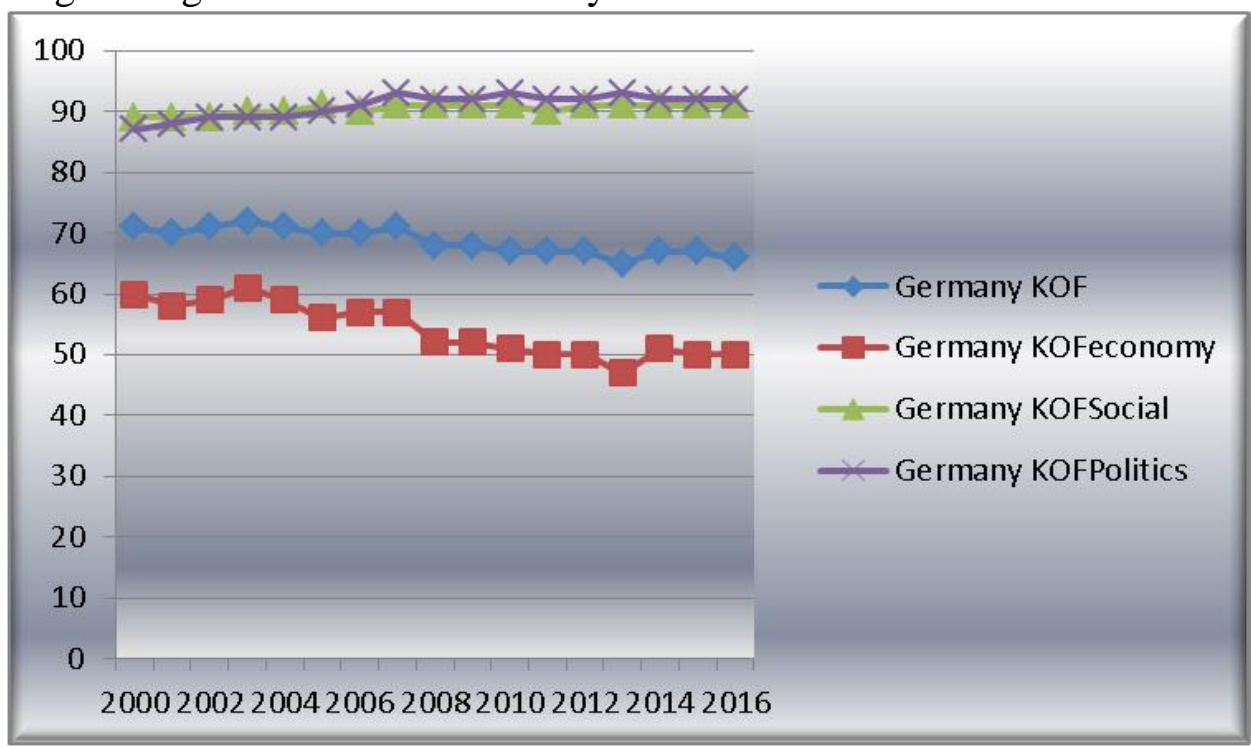

Source: 2018 Globalization Report,

https://www.bertelsmannstiftung.de/fileadmin/files/BSt/Publikationen/GrauePublikationen/MT_Globalization_R eport_2018.pdf

As it can be seen from the figure above, Germany is the most involved in the process of the political globalization. The political process of bringing Germany closer to other EU economies and economies participating in globalization is characterized by over 90 percent integration. It is clear that Germany is an "engine" of political cohesion in the EU. Germany's social integration is the next strongest integration point in which the country again registers convergence of more than 90 percent with the Euro zone countries. It is clear that the political and the social integration are affecting Germany the most. The overall globalization coefficient registered values of 70 percent in the period 2000-2007, and in the following 
period 2007-2016, the values decreased to 67 percent. These dynamics of globalization decrease indicate a turning point in the process of the globalization. This turning point is a reorientation from a globally oriented economic policy to a nationally oriented economic policy. This reorientation has an impact on the economic globalization and its impact on Germany. This impact decreases from 60 percent at the beginning of the period under review to 50 percent by 2016 . The economic globalization also registers the lowest integration coefficient compared to the aggregate, political and social globalization.

Speed of the components of globalization

Figure 2

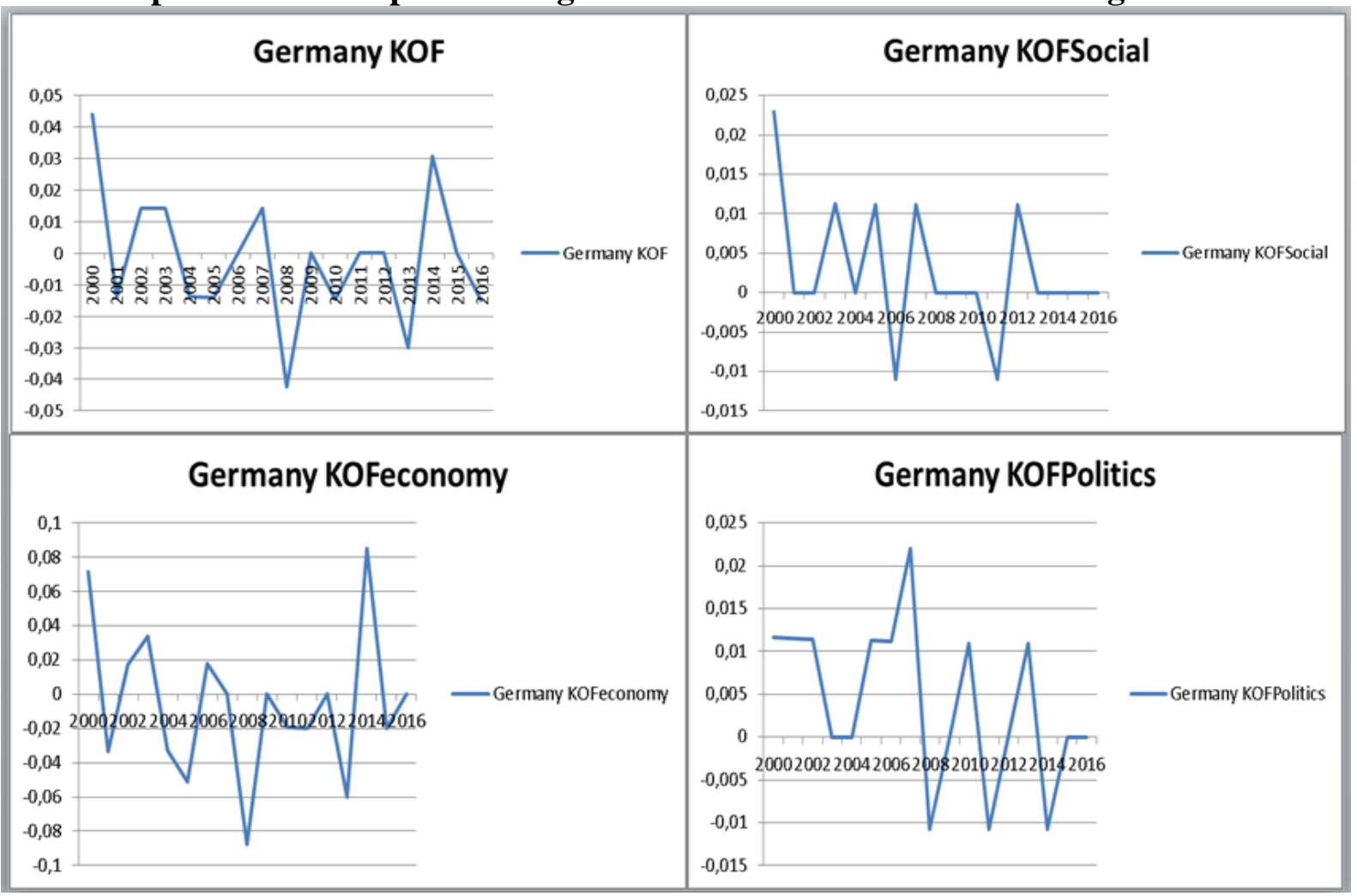

Source: 2018 Globalization Report,

https://www.bertelsmannstiftung.de/fileadmin/files/BSt/Publikationen/GrauePublikationen/MT_Globalization_R eport_2018.pdf.

Data: Authors`research

The speed of globalization of Germany is slowing down, as the aggregate globalization and the economic globalization register a significant slowdown, which at some times goes into disintegration. The political and the social globalization do not account for much slowing down of their speed and are characterized by a positive trajectory of dynamics and speed of development. Therefore, there is an imbalance between the elements of the aggregate globalization, which cannot but result in the economic development of the German economy. The effect on the German economy of the imsbalance of the elements of the globalization and the declining economic and the aggregate globalization in any case have a slow or little effect on the economy of Germany. 


\section{icalalyme}

$2^{\text {nd }}$ International Conference on Advanced Research in

MUNICH, GERMANY

BUSINESS, MANAGEMENT \& ECONOMICS

6 - 8 DECEMBER, 2019

\section{Analysis of the empirical results}

The variables in question - the GDP, economic, political, social and aggregate globalization, are not first-line integrated.

Augmented Dickey-Fuller test

Figure 3

\begin{tabular}{|c|c|c|c|c|}
\hline Augmented Dickey- & Test critica & values: & t-Statistic & Prob. \\
\hline GDP & $1 \%$ level & -4004425 & 1.664233 & 0.9987 \\
\hline & $5 \%$ level & -3.098896 & & \\
\hline & $10 \%$ level & -2.690439 & & \\
\hline KOFSOCIAL & $1 \%$ level & 3.959148 & -2.163775 & 0.2255 \\
\hline & $5 \%$ level & 3.081002 & & \\
\hline & $10 \%$ level & -2.681330 & & \\
\hline KOFPOLITICS & $1 \%$ level & -3.920350 & -2.336521 & 0.1734 \\
\hline & $5 \%$ level & -3.065585 & & \\
\hline & $10 \%$ level & -2.673459 & & \\
\hline KOFECONOMY & $1 \%$ level & -3.920350 & -1.216264 & 0.6400 \\
\hline & $5 \%$ level & -3.065585 & & \\
\hline & $10 \%$ level & -2.673459 & & \\
\hline KOF & $1 \%$ level & -3.920350 & -1.051986 & 0.7073 \\
\hline & $5 \%$ level & -3.065585 & & \\
\hline & $10 \%$ level & -2.673459 & & \\
\hline
\end{tabular}

Source: Eurostat, 2018 Globalization Report,

https://www.bertelsmannstiftung.de/fileadmin/files/BSt/Publikationen/GrauePublikationen/MT_Globalization_R eport_2018.pdf.

Data: Authors`research

The variables are characterized by non-stationarity, which allows the Generalized method of moments (GMM) to be applied.

Determining the issue under consideration is the functional relationship between GDP and the aggregate global index. The impact of globalization on Germany's economic development is a central point to this study. 
Figure 4

\begin{tabular}{|l|r|r|r|r|}
\hline \multicolumn{5}{|c|}{ Method: Generalized Method of Moments } \\
\hline Dependent Variable: GDP & Coefficient & Std. Error & t-Statistic & \multicolumn{1}{|c|}{ Prob. } \\
\hline Variable & 141623.5 & 18580.67 & 7.622087 & 0.0000 \\
\hline C & -1604.880 & 267.3911 & -6.001996 & 0.0000 \\
\hline KOF & 0.761559 & Mean dependent var & 31358.82 \\
\hline R-squared & 0.745662 & S.D. dependent var & 3942.407 \\
\hline Adjusted R-squared & 1988.230 & Sum squared resid & 59295896 \\
\hline S.E. of regression & 1.181512 & J-statistic \\
\hline Durbin-Watson stat & 2 & \multicolumn{4}{l|}{} \\
\hline Instrument rank & &
\end{tabular}

Source: Eurostat, 2018 Globalization Report,

https://www.bertelsmannstiftung.de/fileadmin/files/BSt/Publikationen/GrauePublikationen/MT_Globalization_R eport_2018.pdf.

Data: Authors` research

The globalization index has a negative impact on the economic development of the German economy and accounts for 76 percent of GDP dynamics. This result is expected because, at the end of the period under review, the German policy adopted anti-globalist characteristics. It should also be emphasized that the German economy is highly developed, which is the reason why globalization does not lead to a large and tangible increase in Germany's GDP, but rather to a decrease in its economic development. Another explanation for this negative effect of globalization is the emigration flow in Germany, which puts a strain on its social system and social budgetary payments. At the same time, the social budget payments are increasing for the sake of the emigrants, but this emigrant flow is low-skilled and does not contribute to the GDP growth. Germany's economic rapprochement with the United States and Germany's monetary rapprochement with the Euro zone countries are also having an adverse effect on the German economy, especially after the worsening of the global economic crisis in 2008 and its continuation and spill over into the European debt crisis. These economic shocks inevitably affect the dynamics of German GDP. The globalization favors an easier transfer of negative shocks to the German economy, which have a negative impact on Germany's economic development. Considering the fact that, the period considered covers the range of 2000 until 2016, when the global and European economies were subjected to great economic uncertainty and turbulence, the effect of globalization could not but be negatively impacted on the economic development of the German economy. This negative effect is manifested as a consequence of Germany's economic commitment to the world and European economies. 
Figure 5

\begin{tabular}{|c|r|r|r|r|}
\hline \multicolumn{5}{|c|}{ Method: Generalized Method of Moments } \\
\hline \multicolumn{5}{|c|}{ Dependent Variable: GDP } \\
\hline Variable & Coefficient & Std. Error & t-Statistic & Prob. \\
\hline C & 74063.77 & 6996.028 & 10.58655 & 0.0000 \\
\hline KOFECONOMY & -789.1132 & 121.1470 & -6.513686 & 0.0000 \\
\hline R-squared & 0.780661 & Mean dependent var & 31358.82 \\
\hline Adjusted R-squared & 0.766039 & S.D. dependent var & 3942.407 \\
\hline S.E. of regression & 1906.924 & Sum Squared resid & 54545402 \\
\hline Durbin-Watson stat & 0.971870 & J-statistic & $1.74 \mathrm{E}-43$ \\
\hline Instrument rank & 2 & & \\
\hline
\end{tabular}

Source: Eurostat, 2018 Globalization Report,

https://www.bertelsmannstiftung.de/fileadmin/files/BSt/Publikationen/GrauePublikationen/MT_Globalization_R eport_2018.pdf.

Data: Authors`research

The economic globalization also has a negative impact on Germany's economy. This influence is characterized by a high degree of determination of the economic development of the German economy. The economic cohesion between Germany and the US and EU countries turns out to be a cardinal channel of transmission of negative impulses. Germany is suffering an economic downturn, which is inevitable because of the strong interconnection of the countries participating in the global economic process.

Figure 6

\begin{tabular}{|c|r|r|r|r|}
\hline \multicolumn{5}{|c|}{ Method: Generalized Method of Moments } \\
\hline \multicolumn{4}{|c|}{ Dependent Variable: GDP Moments } \\
\hline Variable & Coefficient & Std. Error & t-Statistic & \multicolumn{1}{|c|}{ Prob. } \\
\hline C & -117266.1 & 29357.32 & -3.994442 & 0.0012 \\
\hline KOFPOLITICS & 1634.298 & 331.1228 & 4.935624 & 0.0002 \\
\hline R-squared & 0.611569 & Mean dependent var & 31358.82 \\
\hline Adjusted R-squared & 0.585674 & S.D. dependent var & 3942.407 \\
\hline S.E. of regression & 2537.655 & Sum squared resid & 96595372 \\
\hline Durbin-Watson stat & 0.382287 & J-statistic & 0.000000 \\
\hline Instrument rank & 2 & & \\
\hline
\end{tabular}

Source: Eurostat, 2018 Globalization Report,

https://www.bertelsmannstiftung.de/fileadmin/files/BSt/Publikationen/GrauePublikationen/MT_Globalization_R eport_2018.pdf.

Data: Authors`research

The political globalization has a very favorable and deterministic impact on Germany's economic development. It is clear that at the heart of EU and euro area policy pursued is the political strategy of Germany and, respectively, the German authorities play a leading role in the EU. The political leadership of Germany creates the preconditions for creating favorable effects for the economic development of the German economy. 
Figure 7

\begin{tabular}{|c|r|r|r|r|}
\hline \multicolumn{5}{|c|}{ Method: Generalized Method of Moments } \\
\hline \multicolumn{5}{|c|}{ Dependent Variable: GDP } \\
\hline Variable & Coefficient & Std. Error & t-Statistic & Prob. \\
\hline C & -287552.9 & 76085.83 & -3.779323 & 0.0018 \\
\hline KOFSOCIAL & 3527.326 & 850.3365 & 4.148153 & 0.0009 \\
\hline R-squared & 0.506206 & Mean dependent var & 31358.82 \\
\hline Adjusted R-squared & 0.473287 & S.D. dependent var & 3942.407 \\
\hline S.E. of regression & 2861.202 & Sum squared resid & $1.23 \mathrm{E}+08$ \\
\hline Durbin-Watson stat & 0.751834 & J-statistic & 0.000000 \\
\hline Instrument rank & 2 & & \\
\hline
\end{tabular}

Source: Eurostat, 2018 Globalization Report,

https://www.bertelsmannstiftung.de/fileadmin/files/BSt/Publikationen/GrauePublikationen/MT_Globalization_R eport_2018.pdf.

Data: Authors`calculations

The social globalization has led to an increase in Germany's GDP. It determines moderately the development of the German economy. The social globalization is an indicator of decreasing inequality and poverty, which contribute to maintaining high domestic demand, leading to a strong positive effect on German GDP. The social integration leads to larger tourist flows in Germany, which contribute to the increase in consumption of the German products. The cultural penetration, as well, creates conditions for the export of German goods from the automotive and light industries, which contributes to the growth of Germany's economic growth.

The analysis made concerning the impact of the globalization on the economic development of the German economy is characterized by both positive and negative effects. The positive effects are determined by the political and social rapprochement of Germany with the countries of Europe and the world, and the negative effects are reproduced by the economic cohesion, which implies the easier and faster transfer of negative foreign economic impulses. Based on the empirical analysis made, the important question arises: "Negative or positive effects affect the German economy more?" The answer to this question can be revealed by the coefficients of determination. The sum of the coefficients of determination of aggregate and economic globalization is greater than the sum of the coefficients of the political and social globalization. Thus, the empirical arguments put forward, lead to the thesis that the globalization has a rather negative effect on the German economy, which in turn causes a change in policy pursued by the German authorities and the turn to an internal national enclosure. However, the in-depth reflections lead us to the thesis that the aggregate globalization is a combination of economic and social, and political globalization. Therefore, the sum of the coefficients of determination of political and social globalization is greater than the coefficient of determination of the economic globalization, which means that the globalization should not have negative effects on the economic growth, but it ultimately leads because the coefficient of the aggregate globalization has a negative sign and has negative effects on the GDP. From the analysis thus made, it follows logically that there is a gap between the economic, political and social element of globalization. It is this gap that leads to the ultimate negative result of the aggregate globalization on Germany's economic growth. 
The gap that logically stands out is between the political and economic globalization, on one hand, and on the other, between the social and economic integration. This gap is repeated again only in the relation between the political and aggregate globalization, and there is a gap between the social and aggregate globalization. It is these internal gaps that create an overall imbalance that negatively affects Germany's economic growth. However, the positive influence of political and social cohesion leads to the conclusion that the impact of the globalization on Germany will continue to manifest itself, with a positive force that will increase after the innovative restructuring of the German economy, which, clearly takes place during the study period.

\section{Conclusion:}

Germany is a highly developed and open economy, which is an active participant in the globalization and a leading factor in the globalization in the EU. The great openness and development of the German economy implies the faster and easier transmission of external economic shocks, which are being absorbed by Germany. Considering the impact of the globalization in the period 2000-2016, which is characterized by global and regional economic turbulence, explains the negative impact of the aggregate globalization on the German economy. The negative effects of economic globalization on the German economy, which are a consequence of the global financial and economic crisis and the debt crisis, are also quite reasonable. These negative shocks of globalization have triggered a reorientation of German policy towards a more global policy, which, however, does not mean stopping the German economy from its global integration, but restructuring German economic policy so as to indicate positive global economic impulses and, at the same time, create a barrier and buffers against the negative economic shocks of globalization. Therefore, the integration of the German economy into the global economy is delayed by the restructuring that takes place under German policy and, on the other hand, by the restructuring of the global process, but the globalization and integration of the German economy will continue regardless of the speed of interaction between them. The positive impact of the political and social globalization on Germany's economic development is an indicator that the German economy will continue to "play" an important role in the global political process and continue to integrate its economy with global economic trends.

The German economy must continue its global integration, which is determined by the fact that the process of globalization may be slow but not halted. Therefore, any policy that does not coordinate with global economic trends is doomed to a future failure.

\section{References:}

1. Hamilton S. D., Quinlan P. J. (2008): „Germany and Globalization“, Washington, DC: Center for Transatlantic Relations.

https://www.files.ethz.ch/isn/96218/2008_GermanyandGlobalization_EN.pdf

2. Hamilton S. D., Quinlan P. J. (2008): „Germany and Globalization“, Washington, DC: Center for Transatlantic Relations, p. 3.

https://www.files.ethz.ch/isn/96218/2008_GermanyandGlobalization_EN.pdf 
3. Dreher, A., (2005): „Does Globalization Affect Growth? Evidence from a new Index of Globalization", Research Paper Series, TWI and University of Konstanz, pp. 2-19 . https://pdfs.semanticscholar.org/a5ce/cb531920ca4afffa4faaf94b0098e4989795.pdf

4.Dreher, A., (2005): „Does Globalization Affect Growth? Evidence from a new Index of Globalization", Research Paper Series, TWI and University of Konstanz, p. 20 https://pdfs.semanticscholar.org/a5ce/cb531920ca4afffa4faaf94b0098e4989795.pdf

5. Dreher, A., (2005): „Does Globalization Affect Growth? Evidence from a new Index of Globalization", Research Paper Series, TWI and University of Konstanz, p. 20 https://pdfs.semanticscholar.org/a5ce/cb531920ca4afffa4faaf94b0098e4989795.pdf

6. Polasek, W., Sellner, R., (2011): Does Globalization Affect Regional Growth? Evidence for NUTS-2 Regions in EU-27, Institute for Advanced Studies, Economics Series 266, Vienna. https://www.ihs.ac.at/publications/eco/es-266.pdf

7. Samimi, P., Jenatabadi, S. H., (2014): Globalization and Economic Growth: Empirical Evidence on the Role of Complementarities, PLOS ONE . https://www.ncbi.nlm.nih.gov/pmc/articles/PMC3982958/

8. https://journals.plos.org/plosone/article?id=10.1371/journal.pone. 0087824

9. Stiglitz, E. J., (2002): „Globalization and Its Discontents“, W.W. Norton \& Company, New York and London, United States of America, First Edition, pp. ix-xi.

10. Noguera S.X., Castro-Martin T., Bonmatí S.A., (2005): The Spanish case: The effects of the globalization process on the transition to Adulthood, In book: Globalization, uncertainty and youth in society, Chapter: 15, Publisher: Routledge.Taylor\&FrancisGroup,pp.373-381.

11. https://www.researchgate.net/publication/257613737_The_Spanish_case_The_effects _of_the_globalization_process_on_the_transition_to_adulthood

12. Vial, A., (2018): Globalisation and the Chilean economy, a chapter in Globalisation and deglobalisation, from Bank for International Settlements, vol. 100, pp 83-100. https://www.bis.org/publ/bppdf/bispap100.pdf

13. Tokman,E., V.,(2010): Globalization in Chile: A Positive Sum of Winners and Losers, International Centre for Trade and Sustainable Development (ICTSD), Geneva, Switzerland, 2010, pp. 33-35.

14. https://www.ictsd.org/sites/default/files/research/2010/12/globalization-in-chile.pdf Brooks, C., (2008):Introductory Econometrics for Finance second edition, The ICMA Centre, University of Reading, p.208.

15. http://www.afriheritage.org/TTT/3\%20Brooks_Introductory\%20Econometrics\%20for $\% 20$ Finance\%20(2nd\%20edition).pdf

16. Brooks, C., (2008): Introductory Econometrics for Finance second edition, The ICMA Centre, University of Reading, p. 208.

17. http://www.afriheritage.org/TTT/3\%20Brooks_Introductory\%20Econometrics\%20for $\% 20$ Finance $\% 20$ (2nd\%20edition).pdf 


\section{Applications:}

Null Hypothesis: GDP has a unit root

Exogenous: Constant

Lag Length: 2 (Automatic - based on SIC, maxlag=3)

\begin{tabular}{lrcc}
\hline \hline & t-Statistic & Prob.* \\
\hline \hline Augmented Dickey-Fuller test statistic & 1.664233 & 0.9987 \\
\hline Test critical values: & $1 \%$ level & -4.004425 & \\
& $5 \%$ level & -3.098896 & \\
$10 \%$ level & -2.690439 & \\
\hline
\end{tabular}

*MacKinnon (1996) one-sided p-values.

Warning: Probabilities and critical values calculated for 20 observations and may not be accurate for a sample size of 14

Augmented Dickey-Fuller Test Equation

Dependent Variable: D(GDP_1)

Method: Least Squares

Date: 11/11/19 Time: 20:08

Sample (adjusted): 20032016

Included observations: 14 after adjustments

\begin{tabular}{lrlrr}
\hline \hline \multicolumn{1}{c}{ Variable } & Coefficient & \multicolumn{1}{c}{ Std. Error } & t-Statistic & Prob. \\
\hline \hline \multicolumn{1}{c}{ GDP_1(-1) } & 0.099903 & 0.060030 & 1.664233 & 0.1270 \\
D(GDP_1(-1)) & -0.228553 & 0.269772 & -0.847208 & 0.4167 \\
D(GDP_1(-2)) & -0.641248 & 0.265720 & -2.413246 & 0.0365 \\
\multicolumn{1}{c}{ C } & -1702.125 & 1765.414 & -0.964151 & 0.3577 \\
\hline \hline R-squared & 0.394427 & Mean dependent var & 807.1429 \\
Adjusted R-squared & 0.212755 & S.D. dependent var & 706.5238 \\
S.E. of regression & 626.8761 & Akaike info criterion & 15.95433 \\
Sum squared resid & 3929737. & Schwarz criterion & 16.13692 \\
Log likelihood & -107.6803 & Hannan-Quinn criter. & 15.93743 \\
F-statistic & 2.171094 & Durbin-Watson stat & 2.313087 \\
Prob(F-statistic) & 0.154628 & & \\
\hline
\end{tabular}

Null Hypothesis: KOF has a unit root

Exogenous: Constant

Lag Length: 0 (Automatic - based on SIC, maxlag=3)

\begin{tabular}{lrrr}
\hline \hline & t-Statistic & \multicolumn{1}{c}{ Prob.* } \\
\hline \hline Augmented Dickey-Fuller test statistic & -1.051986 & 0.7073 \\
\hline Test critical values: & $1 \%$ level & -3.920350 & \\
& $5 \%$ level & -3.065585 & \\
& $10 \%$ level & -2.673459 & \\
\hline \hline
\end{tabular}

*MacKinnon (1996) one-sided p-values. 
Warning: Probabilities and critical values calculated for 20 observations and may not be accurate for a sample size of 16

Augmented Dickey-Fuller Test Equation

Dependent Variable: D(KOF)

Method: Least Squares

Date: 11/11/19 Time: 20:08

Sample (adjusted): 20012016

Included observations: 16 after adjustments

\begin{tabular}{lrlrr}
\hline \hline \multicolumn{1}{c}{ Variable } & Coefficient & \multicolumn{1}{c}{ Std. Error } & t-Statistic & Prob. \\
\hline \hline \multicolumn{1}{c}{ KOF(-1) } & -0.161597 & 0.153611 & -1.051986 & 0.3106 \\
\multicolumn{1}{c}{ C } & 10.81749 & 10.58456 & 1.022006 & 0.3241 \\
\hline \hline R-squared & 0.073257 & Mean dependent var & -0.312500 \\
Adjusted R-squared & 0.007061 & S.D. dependent var & 1.250000 \\
S.E. of regression & 1.245579 & Akaike info criterion & 3.393546 \\
Sum squared resid & 21.72053 & Schwarz criterion & 3.490120 \\
Log likelihood & -25.14837 & Hannan-Quinn criter. & 3.398492 \\
F-statistic & 1.106674 & Durbin-Watson stat & 2.422027 \\
Prob(F-statistic) & 0.310626 & & \\
\hline
\end{tabular}

Null Hypothesis: KOFECONOMY has a unit root

Exogenous: Constant

Lag Length: 0 (Automatic - based on SIC, maxlag=3)

\begin{tabular}{lrrr}
\hline \hline & t-Statistic & Prob.* \\
\hline \hline Augmented Dickey-Fuller test statistic & -1.216264 & 0.6400 \\
\hline Test critical values: & 1\% level & -3.920350 & \\
& $5 \%$ level & -3.065585 & \\
& $10 \%$ level & -2.673459 & \\
\hline \hline
\end{tabular}

*MacKinnon (1996) one-sided p-values.

Warning: Probabilities and critical values calculated for 20 observations and may not be accurate for a sample size of 16

Augmented Dickey-Fuller Test Equation

Dependent Variable: D(KOFECONOMY)

Method: Least Squares

Date: 11/11/19 Time: 20:08

Sample (adjusted): 20012016

Included observations: 16 after adjustments

\begin{tabular}{crcrr}
\hline \hline Variable & Coefficient & Std. Error & t-Statistic & Prob. \\
\hline \hline KOFECONOMY(-1) & -0.150638 & 0.123853 & -1.216264 & 0.2440 \\
C & 7.565957 & 6.755399 & 1.119987 & 0.2816 \\
\hline \hline R-squared & 0.095566 & Mean dependent var & -0.625000
\end{tabular}




$\begin{array}{lrll}\text { Adjusted R-squared } & 0.030964 & \text { S.D. dependent var } & 2.156386 \\ \text { S.E. of regression } & 2.122738 & \text { Akaike info criterion } & 4.459760 \\ \text { Sum squared resid } & 63.08426 & \text { Schwarz criterion } & 4.556333 \\ \text { Log likelihood } & -33.67808 & \text { Hannan-Quinn criter. } & 4.464705 \\ \text { F-statistic } & 1.479298 & \text { Durbin-Watson stat } & 2.441293 \\ \text { Prob(F-statistic) } & 0.243994 & & \end{array}$

Null Hypothesis: KOFPOLITICS has a unit root

Exogenous: Constant

Lag Length: 0 (Automatic - based on SIC, maxlag=3)

\begin{tabular}{lrrr}
\hline \hline & t-Statistic & Prob. $^{*}$ \\
\hline \hline Augmented Dickey-Fuller test statistic & -2.336521 & 0.1734 \\
\hline Test critical values: & 1\% level & -3.920350 & \\
& $5 \%$ level & -3.065585 & \\
& $10 \%$ level & -2.673459 & \\
\hline \hline
\end{tabular}

*MacKinnon (1996) one-sided p-values.

Warning: Probabilities and critical values calculated for 20 observations and may not be accurate for a sample size of 16

Augmented Dickey-Fuller Test Equation

Dependent Variable: D(KOFPOLITICS)

Method: Least Squares

Date: 11/11/19 Time: 20:08

Sample (adjusted): 20012016

Included observations: 16 after adjustments

\begin{tabular}{lrlrr}
\hline \hline \multicolumn{1}{c}{ Variable } & Coefficient & \multicolumn{1}{c}{ Std. Error } & t-Statistic & Prob. \\
\hline \hline \multicolumn{1}{c}{ KOFPOLITICS(-1) } & -0.239910 & 0.102678 & -2.336521 & 0.0348 \\
\multicolumn{1}{c}{ C } & 22.11435 & 9.332869 & 2.369512 & 0.0327 \\
\hline \hline R-squared & 0.280551 & Mean dependent var & 0.312500 \\
Adjusted R-squared & 0.229162 & S.D. dependent var & 0.873212 \\
S.E. of regression & 0.766658 & Akaike info criterion & 2.422916 \\
Sum squared resid & 8.228700 & Schwarz criterion & 2.519490 \\
Log likelihood & -17.38333 & Hannan-Quinn criter. & 2.427862 \\
F-statistic & 5.459332 & Durbin-Watson stat & 2.371040 \\
Prob(F-statistic) & 0.034847 & & \\
\hline \hline
\end{tabular}

Null Hypothesis: KOFSOCIAL has a unit root

Exogenous: Constant

Lag Length: 1 (Automatic - based on SIC, maxlag=3)

\begin{tabular}{lcc}
\hline \hline & t-Statistic & Prob.* \\
\hline \hline Augmented Dickey-Fuller test statistic & -2.163775 & 0.2255 \\
\hline Test critical values: $\quad$ 1\% level & -3.959148 &
\end{tabular}



$5 \%$ level
$-3.081002$
$10 \%$ leve
$-2.681330$

*MacKinnon (1996) one-sided p-values.

Warning: Probabilities and critical values calculated for 20 observations and may not be accurate for a sample size of 15

Augmented Dickey-Fuller Test Equation

Dependent Variable: D(KOFSOCIAL)

Method: Least Squares

Date: 11/11/19 Time: 20:09

Sample (adjusted): 20022016

Included observations: 15 after adjustments

\begin{tabular}{lrlrr}
\hline \hline \multicolumn{1}{c}{ Variable } & Coefficient & \multicolumn{1}{c}{ Std. Error } & t-Statistic & Prob. \\
\hline \hline \multicolumn{1}{c}{ KOFSOCIAL(-1) } & -0.394343 & 0.182248 & -2.163775 & 0.0514 \\
D(KOFSOCIAL(-1)) & -0.427621 & 0.211661 & -2.020305 & 0.0662 \\
\multicolumn{1}{c}{ C } & 35.86522 & 16.47907 & 2.176411 & 0.0502 \\
\hline \hline R-squared & 0.514182 & Mean dependent var & 0.133333 \\
Adjusted R-squared & 0.433212 & S.D. dependent var & 0.639940 \\
S.E. of regression & 0.481781 & Akaike info criterion & 1.554203 \\
Sum squared resid & 2.785358 & Schwarz criterion & 1.695813 \\
Log likelihood & -8.656524 & Hannan-Quinn criter. & 1.552695 \\
F-statistic & 6.350299 & Durbin-Watson stat & 2.221719 \\
Prob(F-statistic) & 0.013147 & & \\
\hline \hline
\end{tabular}

Dependent Variable: GDP

Method: Generalized Method of Moments

Date: 11/11/19 Time: 20:09

Sample: 20002016

Included observations: 17

Linear estimation with 1 weight update

Estimation weighting matrix: HAC (Bartlett kernel, Newey-West fixed bandwidth $=3.0000$ )

Standard errors \& covariance computed using HAC weighting matrix

(Bartlett kernel, Newey-West fixed bandwidth $=3.0000$ )

Instrument specification: $\mathrm{KOF}$

Constant added to instrument list

\begin{tabular}{lrlrr}
\hline \hline \multicolumn{1}{c}{ Variable } & Coefficient & Std. Error & t-Statistic & Prob. \\
\hline \hline \multicolumn{1}{c}{ KOF } & 141623.5 & 18580.67 & 7.622087 & 0.0000 \\
\multicolumn{1}{c}{-1604.880} & 267.3911 & -6.001996 & 0.0000 \\
\hline \hline R-squared & 0.761559 & Mean dependent var & 31358.82 \\
Adjusted R-squared & 0.745662 & S.D. dependent var & 3942.407 \\
S.E. of regression & 1988.230 & Sum squared resid & 59295896 \\
Durbin-Watson stat & 1.181512 & J-statistic & 0.000000 \\
Instrument rank & 2 & & \\
\hline \hline
\end{tabular}


Dependent Variable: GDP

Method: Generalized Method of Moments

Date: 11/11/19 Time: 20:10

Sample: 20002016

Included observations: 17

Linear estimation with 1 weight update

Estimation weighting matrix: HAC (Bartlett kernel, Newey-West fixed bandwidth $=3.0000$ )

Standard errors \& covariance computed using HAC weighting matrix

(Bartlett kernel, Newey-West fixed bandwidth $=3.0000$ )

Instrument specification: KOFECONOMY

Constant added to instrument list

\begin{tabular}{lrlrr}
\hline \hline \multicolumn{1}{c}{ Variable } & Coefficient & \multicolumn{1}{c}{ Std. Error } & t-Statistic & Prob. \\
\hline \hline \multicolumn{1}{c}{ C } & 74063.77 & 6996.028 & 10.58655 & 0.0000 \\
\multicolumn{1}{c}{ KOFECONOMY } & -789.1132 & 121.1470 & -6.513686 & 0.0000 \\
\hline \hline R-squared & 0.780661 & Mean dependent var & 31358.82 \\
Adjusted R-squared & 0.766039 & S.D. dependent var & 3942.407 \\
S.E. of regression & 1906.924 & Sum squared resid & 54545402 \\
Durbin-Watson stat & 0.971870 & J-statistic & $1.74 \mathrm{E}-43$ \\
Instrument rank & 2 & & \\
\hline
\end{tabular}

Dependent Variable: GDP

Method: Generalized Method of Moments

Date: 11/11/19 Time: 20:10

Sample: 20002016

Included observations: 17

Linear estimation with 1 weight update

Estimation weighting matrix: HAC (Bartlett kernel, Newey-West fixed bandwidth $=3.0000$ )

Standard errors \& covariance computed using HAC weighting matrix

(Bartlett kernel, Newey-West fixed bandwidth $=3.0000$ )

Instrument specification: KOFPOLITICS

Constant added to instrument list

\begin{tabular}{lrrrr}
\hline \hline \multicolumn{1}{c}{ Variable } & Coefficient & \multicolumn{1}{c}{ Std. Error } & t-Statistic & Prob. \\
\hline \hline \multicolumn{1}{c}{ C } & -117266.1 & 29357.32 & -3.994442 & 0.0012 \\
\multicolumn{1}{c}{ KOFPOLITICS } & 1634.298 & 331.1228 & 4.935624 & 0.0002 \\
\hline \hline R-squared & 0.611569 & Mean dependent var & 31358.82 \\
Adjusted R-squared & 0.585674 & S.D. dependent var & 3942.407 \\
S.E. of regression & 2537.655 & Sum squared resid & 96595372 \\
Durbin-Watson stat & 0.382287 & J-statistic & 0.000000 \\
Instrument rank & 2 & & \\
\hline \hline
\end{tabular}

Dependent Variable: GDP 
Method: Generalized Method of Moments

Date: 11/11/19 Time: 20:11

Sample: 20002016

Included observations: 17

Linear estimation with 1 weight update

Estimation weighting matrix: HAC (Bartlett kernel, Newey-West fixed bandwidth $=3.0000$ )

Standard errors \& covariance computed using HAC weighting matrix

(Bartlett kernel, Newey-West fixed bandwidth $=3.0000)$

Instrument specification: KOFSOCIAL

Constant added to instrument list

\begin{tabular}{lrrrr}
\hline \hline \multicolumn{1}{c}{ Variable } & Coefficient & \multicolumn{1}{c}{ Std. Error } & t-Statistic & Prob. \\
\hline \multicolumn{1}{c}{ C } & -287552.9 & 76085.83 & -3.779323 & 0.0018 \\
\multicolumn{1}{c}{ KOFSOCIAL } & 3527.326 & 850.3365 & 4.148153 & 0.0009 \\
\hline \hline R-squared & 0.506206 & Mean dependent var & 31358.82 \\
Adjusted R-squared & 0.473287 & S.D. dependent var & 3942.407 \\
S.E. of regression & 2861.202 & Sum squared resid & $1.23 \mathrm{E}+08$ \\
Durbin-Watson stat & 0.751834 & J-statistic & 0.000000 \\
Instrument rank & 2 & & \\
\hline \hline
\end{tabular}

